\title{
Hubungan Tingkat Pencahayaan, Kelembaban Udara, dan Ventilasi udara dengan Faktor Risiko Kejadian TB Paru BTA Positif di Desa Jatikalang Kecamatan Krian Kabupaten Sidoarjo
}

\author{
Sukma Sahadewa1*, Eufemia², Edwin², Ni Luh², Shita² \\ Bagian Ilmu Kesehatan Masyarakat, Fakultas Kedokteran, \\ Universitas Wijaya Kusuma Surabaya ${ }^{1}$ \\ Fakultas Kedokteran, \\ Universitas Wijaya Kusuma Surabaya ${ }^{2}$ \\ *e-mail: sukmasahadewa83@gmail.com
}

\begin{abstract}
Abstrak
Tuberkulosis adalah penyakit menular yang disebabkan oleh Mycobaterium tuberculosis yang dapat dipengaruhi oleh beberapa faktor. Kondisi fisik lingkungan rumah yang tidak sehat memegang peranan penting dalam penularan dan perkembangbiakan Mycobacterium tuberculosis. Tujuan penelitian untuk mengetahui hubungan antara tingkat pencahayaan, kelembaban udara, dan ventilasi udara dengan faktor risiko kejadian Tuberkulosis Paru Bakteri Tahan Asam positif di Desa Jatikalang Kecamatan Krian Kabupaten Sidoarjo. Populasi kasus pada penelitian ini adalah seluruh penderita yang dinyatakan tuberkulosis paru BTA+ yang datang ke Puskesmas Krian periode antara Januari 2017 - Desember 2017 dengan besar sampel sebanyak 34 responden. Analisis data yang digunakan adalah uji odds ratio. Hasil analisis diketahui adanya hubungan yang bermakna antara ventilasi rumah tinggal dengan kejadian Tuberkulosis Paru dimana diperoleh $p$-value $=0,006(<0,05)$ dan nilai $\mathrm{OR}=7,800(>1)$. Hal ini menunjukkan bahwa ventilasi rumah yang buruk mempunyai risiko 7,800 kali lebih besar untuk mengalami kejadian TB paru.
\end{abstract}

Kata Kunci: Kondisi Lingkungan, TB Paru, BTA Positif

\section{The Relationship between Lighting, Air Humidity and Air Ventilation Levels with the Risk Factors of Positive Acid Resistant Bacteria TB in Jatikalang Village, Krian District, Sidoarjo Regency}

\begin{abstract}
Tuberculosis is an infectious disease caused by Mycobaterium tuberculosis which can be influenced by several factors. The physical condition of an unhealthy home environment plays an important role in the transmission and proliferation of Mycobacterium tuberculosis. The aim of theis study was to know the relationship between lighting levels, air humidity, and air ventilation with risk factors for positive Acid resistant bacteria pulmonary TB incidence in Jatikalang Village, Krian District, Sidoarjo Regency. The population of the cases in this study were all patients who were declared positive result of Acid resistant bacteriapulmonary tuberculosis who came to the Krian Health Center for the period January 2017 - December 2017 with a sample size of 34 respondents. The data analysis was used is the odds ratio test. The results of the analysis showed that there was a significant relationship between home ventilation and the incidence of tuberculosis with $p$-value $=0.006(<0.05)$ and $O R=7.800(>1)$
\end{abstract}


Hubungan Tingkat Pencahayaan, Kelembaban Udara, dan Ventilasi udara dengan Faktor...

Sukma Sahadewa, Eufemia, Edwin, Ni Luh, Shita

are obtained. The result showed that poor home ventilation has a risk of 7,800 times greater to experience the incidence of pulmonary TB.

Keywords: Environmental Conditions, Pulmonary TB, Positive acid resistant bacteria

\section{PENDAHULUAN}

Tuberkulosis adalah penyakit menular yang langsung disebabkan oleh kuman Mycobaterium tuberkulosis. Sekitar sepertiga penduduk dunia telah terinfeksi oleh Mycobaterium tuberkulosis. Ada 9 juta pasien tuberkulosis paru dan 3 juta kematian akibat Tuberkulosis paru di seluruh dunia, diperkira kan 95\% kasus Tuberkulosis paru dan 98\% kematian Tuberkulosis paru didunia terjadi di negara sedang berkembang (Kemenkes, 2011).

Indonesia sampai dengan tahun 2014 menempati urutan kedua dari 5 negara terbesar di dunia sebagai penyumbang penderita TB terbanyak setelah negara India, China, Nigeria dan Pakistan. Pada tahun 2015, beban dunia terkait penyakit TB (prevalensi dan mortalitas) akan relatif berkurang sebesar $50 \%$ dibandingkan tahun 1990, dan setidaknya $70 \%$ orang yang terinfeksi TB dapat dideteksi dengan strategi DOTS dan $85 \%$ diantaranya dinyatakan sembuh (Kemenkes RI, 2015).

Pada tahun 2016 ditemukan jumlah kasus baru BTA positif (BTA+) sebanyak 156.723 kasus yang menurun bila dibandingkan kasus baru BTA+ yang ditemukan tahun 2015 yang sebesar 202.301 kasus. Jumlah kasus tertinggi yang dilaporkan terdapat di provinsi dengan jumlah penduduk yang besar yaitu Jawa Barat, Jawa Timur, dan Jawa Tengah. Kasus baru BTA (+) di tiga provinsi tersebut hampir sebesar $50 \%$ dari jumlah seluruh kasus baru di Indonesia (Kemenkes RI, 2017).

Dari data yang didapatkan di Puskesmas Krian, Kabupaten Sidoarjo, angka penemuan kasus baru BTA (+) terhadap dugaan pada tahun 2017 sebesar $12,20 \%$, apabila dibandingkan dengan tahun 2016 angka tersebut turun 1,03\%. Kasus baru BTA (+) pada tahun 2017 ini banyak ditemukan dari penduduk Desa Jatikalang yaitu 15 dari 42 kasus (Profil Kesehatan Puskesmas Krian, 2017).

Terjadinya kasus tuberkulosis paru dapat dipengaruhi oleh beberapa faktor, di antaranya adalah kondisi fisik lingkungan rumah. Kualitas lingkungan fisik rumah yang tidak sehat memegang peranan penting dalam penularan dan perkembang biakan Mycobacterium tuberculosis. Kurangnya sinar matahari yang masuk ke dalam rumah, ventilasi yang buruk cenderung menciptakan suasana yang 
ISSN 1978-2071 (Print); ISSN 2580-5967 (Online) Jurnal IImiah Kedokteran Wijaya Kusuma 8(2) : 118-130, September 2019

lembab dan gelap, kondisi ini menyebabkan kuman dapat bertahan berhari-hari sampai berbulan - bulan di dalam rumah. Faktor risiko lingkungan fisik rumah yang berperan dalam menentukan terjadinya interaksi antara host (penjamu) dengan unsur penyebab (agent) dalam proses timbulnya kejadian penyakit tuberkulosis paru yaitu kepadatan penghuni, kelembaban, luas ventilasi, pencahayaan, lantai dan dinding rumah (Agustian, 2014).

Kondisi fisik rumah memiliki peranan yang sangat penting dalam penyebaran bakteri tuberkulosis paru ke orang yang sehat. Sumber penularan penyakit ini melalui perantaraan ludah atau dahak penderita yang mengandung Mycobacterium tuberkulosis. Pada saat penderita batuk atau bersin butir-butir air ludah beterbangan di udara dan akan hidup beberapa jam lamanya (Naga, 2014) di dalam ruangan lembab dan kurang cahaya. Penyebaran bakteri tuberkulosis paru akan lebih cepat menyerang orang yang sehat jika berada di dalam rumah yang lembab, gelap dan kurang cahaya (Kemenkes, 2011).

Dari uraian permasalahan di atas penulis mencoba untuk mengetahui apakah ada hubungan antara kondisi fisik lingkungan rumah dengan kejadian TB Paru
BTA (+) di Desa Jatikalang Kecamatan Krian Kabupaten Sidoarjo.

\section{METODE PENELITIAN}

\section{Rancangan Penelitian}

Jenis penelitian adalah penelitian Survei Analitik, dengan rancangan Case Control untuk membandingkan kelompok kasus dan kelompok kontrol berdasarkan status paparannya

\section{Populasi dan Sampel Penelitian}

Populasi kasus pada penelitian ini adalah seluruh penderita yang dinyatakan tuberkulosis paru BTA (+) yang datang ke Puskesmas Krian dan tercatat di register TB UPK Puskesmas Krian pada periode Januari 2017 - Desember 2017 dengan besar sampel sebanyak 34 responden

\section{Metode Analisis Data}

Adapun analisis data yang digunakan adalah analisis univariat dan analisis bivariat. Analisis univariat dilakukan untuk mengetahui distribusi frekuensi dan presentase setiap variabel yang kemudian disajikan dalam bentuk tabel dan di interpretasikan. Pada analisis bivariat, dilakukan terhadap dua variabel yang diduga berhubungan atau menggunakan uji statistik Chi Square (X2) dengan derajat kepercayaan 95\% $(\alpha=0,05)$. Hubungan dikatakan bermakna apabila $\mathrm{P}<0,05$ dan melihat nilai Odds Ratio (OR) untuk memperkirakan risiko masing-masing variabel yang diteliti. 
Hubungan Tingkat Pencahayaan, Kelembaban Udara, dan Ventilasi udara dengan Faktor...

Sukma Sahadewa, Eufemia, Edwin, Ni Luh, Shita

\section{HASIL PENELITIAN}

Karasteristik mengenai responden penelitian dapat dilihat pada tabel di bawah ini:

\section{Jenis Kelamin Responden}

Tabel 1. Distribusi Frekuensi Kasus dan Kontrol Berdasarkan Jenis Kelamin Responden di Puskesmas Krian

\begin{tabular}{lcccccc}
\hline \multirow{2}{*}{$\begin{array}{c}\text { Jenis } \\
\text { Kelamin }\end{array}$} & \multicolumn{4}{c}{ TB } & \multirow{2}{*}{ Jumlah } \\
\cline { 2 - 6 } & \multicolumn{2}{c}{ Positif } & \multicolumn{2}{c}{ Negatif } & & \\
\cline { 2 - 6 } & $\mathrm{n}$ & $\%$ & $\mathrm{n}$ & $\%$ & $\mathrm{n}$ & $\%$ \\
\hline Laki-laki & 12 & 70,6 & 6 & 35,3 & 18 & 52,9 \\
\hline Perempuan & 5 & 29,4 & 11 & 64,7 & 16 & 47,1 \\
\hline Total & 17 & 100 & 17 & 100 & 34 & 100.0 \\
\hline
\end{tabular}

Sumber : Hasil survei 2018

Pada tabel di atas diketahui bahwa sebagian besar proporsi kelompok kasus yang menderita TB paru adalah laki-laki $(70,6 \%)$ lebih tinggi dibanding dengan kelompok kontrol $(35,3 \%)$.

\section{Pendidikan Responden}

Tabel 2. Distribusi Frekuensi Kasus dan Kontrol Berdasarkan Pendidikan Responden di Puskesmas Krian

\begin{tabular}{lccccccc}
\hline \multirow{2}{*}{ Pendidikan } & \multicolumn{4}{c}{ TB } & \multirow{2}{*}{ Jumlah } \\
\cline { 2 - 6 } & Positif & \multicolumn{3}{c}{ Negatif } & & \\
\cline { 2 - 6 } & $\mathrm{n}$ & $\%$ & $\mathrm{n}$ & $\%$ & $\mathrm{n}$ & $\%$ \\
\hline Tidak Sekolah/ & 1 & 5,9 & 1 & 5,9 & 2 & 5,9 \\
Tamat SD & 12 & 70,6 & 12 & 70,6 & 24 & 70,6 \\
\hline Tamat SMP & 12 & 23,5 & 4 & 23,5 & 8 & 23,5 \\
\hline Tamat SMA & 17 & 100 & 17 & 100 & 34 & 100.0 \\
\hline Total & 4 & & & & & & \\
\hline
\end{tabular}

Sumber : Hasil survei 2018

Pada tabel di atas diketahui bahwa sebagian besar proporsi kelompok kasus yang menderita TB paru adalah tamatan SMP $(70,6 \%)$ sebanding dengan kelompok kontrol yang juga berasal dari lulusan SMP (70,6\%).

\section{Pekerjaan Responden}

Tabel 3. Distribusi Frekuensi Kasus dan Kontrol Berdasarkan Pekerjaan Responden di Puskesmas Krian

\begin{tabular}{|c|c|c|c|c|c|c|}
\hline \multirow{3}{*}{ Pekerjaan } & \multicolumn{4}{|c|}{ TB } & \multirow{2}{*}{\multicolumn{2}{|c|}{ Jumlah }} \\
\hline & \multicolumn{2}{|c|}{ Positif } & \multicolumn{2}{|c|}{ Negatif } & & \\
\hline & $\mathrm{n}$ & $\%$ & $\mathrm{n}$ & $\%$ & $n$ & $\%$ \\
\hline $\begin{array}{l}\text { PNS/ Polri/ } \\
\text { Pensiunan }\end{array}$ & 2 & 11,8 & 1 & 5,9 & 3 & 8,8 \\
\hline $\begin{array}{l}\text { Pegawai } \\
\text { swasta/ } \\
\text { wiraswsata }\end{array}$ & 9 & 52,9 & 11 & 64,7 & 20 & 58,8 \\
\hline Buruh & 6 & 35,3 & 5 & 29,4 & 11 & 32,4 \\
\hline Total & 17 & 100 & 17 & 100 & 34 & 100.0 \\
\hline
\end{tabular}

Pada tabel di atas diketahui bahwa sebagian besar proporsi kelompok kasus yang menderita TB paru adalah pegawai swasta atau wiraswasta (52,9\%) lebih rendah dibandingkan dengan kelompok kontrol $(64,7 \%)$.

4. Jenis Dinding Rumah Responden

Tabel 4. Distribusi Frekuensi Kasus dan Kontrol Berdasarkan Jenis Dinding Rumah Responden di Puskesmas Krian

\begin{tabular}{|c|c|c|c|c|c|c|}
\hline \multirow{3}{*}{$\begin{array}{l}\text { Jenis Dinding } \\
\text { Rumah }\end{array}$} & \multicolumn{4}{|c|}{ TB } & \multirow{2}{*}{\multicolumn{2}{|c|}{ Jumlah }} \\
\hline & \multicolumn{2}{|c|}{ Positif } & \multicolumn{2}{|c|}{ Negatif } & & \\
\hline & $\mathrm{n}$ & $\%$ & $\mathrm{n}$ & $\%$ & $\mathrm{n}$ & $\%$ \\
\hline $\begin{array}{l}\text { Bilik bambu/ } \\
\text { papan kayu }\end{array}$ & 1 & 5,9 & 0 & 0 & 1 & 2,9 \\
\hline $\begin{array}{l}\text { Pasangan } \\
\text { batako/ bata } \\
\text { tanpa plester }\end{array}$ & 11 & 64,7 & 13 & 76,5 & 24 & 70,6 \\
\hline $\begin{array}{l}\text { Pasangan } \\
\text { batako/ bata } \\
\text { dengan plester }\end{array}$ & 5 & 29,4 & 4 & 23,5 & 9 & 26,5 \\
\hline Total & 17 & 100 & 17 & 100 & 34 & 100.0 \\
\hline
\end{tabular}


ISSN 1978-2071 (Print); ISSN 2580-5967 (Online) Jurnal IImiah Kedokteran Wijaya Kusuma 8(2) : 118-130, September 2019

Pada tabel di atas diketahui bahwa sebagian besar proporsi kelompok kasus yang menderita TB paru adalah yang mempunyai jenis lantai pasang batako/bata tanpa plester $(64,7 \%)$ yang lebih rendah dibandingkan dengan kelompok kontrol $(76,5 \%)$

\section{Kondisi Dinding Rumah Responden}

Tabel 5. Distribusi Frekuensi Kasus dan Kontrol Berdasarkan Kondisi Dinding Rumah Responden di Puskesmas Krian

\begin{tabular}{lcccccc}
\hline \multirow{2}{*}{$\begin{array}{l}\text { Kondisi } \\
\text { dinding }\end{array}$} & \multicolumn{3}{c}{ TB } & \multirow{2}{*}{ Jumlah } \\
\cline { 2 - 6 } & Positif & \multicolumn{2}{c}{ Negatif } & & \\
\cline { 2 - 6 } & $\mathrm{n}$ & $\%$ & $\mathrm{n}$ & $\%$ & $\mathrm{n}$ & $\%$ \\
\hline Lembab & 10 & 58,8 & 5 & 29,4 & 15 & 44,1 \\
\hline Kering & 7 & 41,2 & 12 & 70,6 & 19 & 55,9 \\
\hline Total & 17 & 100 & 17 & 100 & 34 & 100.0 \\
\hline Sumber: Hasil survei 2018
\end{tabular}

Pada tabel di atas diketahui bahwa sebagian besar proporsi kelompok kasus yang menderita TB paru adalah yang mempunyai kondisi dinding rumah yang lembab (58,8\%) lebih tinggi dibandingkan dengan kelompok kontrol $(29,4 \%)$.

6. Bahan Lantai Rumah Responden

Tabel 6. Distribusi Frekuensi Kasus dan Kontrol Berdasarkan Bahan Lantai Rumah Responden di Puskesmas Krian

\begin{tabular}{lcccccc}
\hline \multirow{2}{*}{ Bahan Lantai } & \multicolumn{4}{c}{ TB } & \multirow{2}{*}{ Jumlah } \\
\cline { 2 - 6 } & Positif & \multicolumn{2}{c}{ Negatif } & & \\
\cline { 2 - 6 } & $\mathrm{n}$ & $\%$ & $\mathrm{n}$ & $\%$ & $\mathrm{n}$ & $\%$ \\
\hline Tanah/papan & 2 & 11,8 & 4 & 23,5 & 6 & 17,6 \\
\hline $\begin{array}{l}\text { Plester/ } \\
\text { keramik }\end{array}$ & 15 & 88,2 & 13 & 76,5 & 28 & 82,4 \\
\hline Total & 17 & 100 & 17 & 100 & 34 & 100.0 \\
\hline
\end{tabular}

Sumber : Hasil survei 2018

Pada tabel di atas diketahui bahwa sebagian besar proporsi kelompok kasus yang menderita TB paru adalah yang mempunyai kondisi bahan lantai rumah plester/keramik $(88,2 \%)$ lebih tinggi dibandingkan dengan kelompok kontrol (76,5\%).

7. Sinar Matahari Yang Masuk Rumah Responden

Tabel 7. Distribusi Frekuensi Kasus dan Kontrol Berdasarkan Sinar Matahari Yang Masuk Rumah Responden di Puskesmas Krian

\begin{tabular}{|c|c|c|c|c|c|c|}
\hline \multirow{3}{*}{$\begin{array}{c}\text { Sinar } \\
\text { matahari } \\
\text { yang } \\
\text { masuk } \\
\text { rumah }\end{array}$} & \multicolumn{4}{|c|}{ TB } & \multirow{2}{*}{\multicolumn{2}{|c|}{ Jumlah }} \\
\hline & \multicolumn{2}{|c|}{ Positif } & \multicolumn{2}{|c|}{ Negatif } & & \\
\hline & $\mathrm{n}$ & $\%$ & $n$ & $\%$ & $n$ & $\%$ \\
\hline Ya & 8 & 47,1 & 11 & 64,7 & 19 & 55,9 \\
\hline Tidak & 9 & 52,9 & 6 & 35,3 & 15 & 44,1 \\
\hline Total & 17 & 100 & 17 & 100 & 34 & 100.0 \\
\hline
\end{tabular}

Sumber : Hasil survei 2018

Pada tabel di atas diketahui bahwa sebagian besar proporsi kelompok kasus yang menderita TB paru dengan sinar matahari yang tidak masuk ke rumah $(52,9 \%)$ lebih tinggi dibandingkan dengan kelompok kontrol $(35,3)$

8. Tuberkulosis Paru Responden

Tabel 8. Kasus Tuberkulosis dan Kelompok Kontrol Penelitian

\begin{tabular}{lcc}
\hline Tuberkulosis Paru & Frekuensi & $\begin{array}{c}\text { Persentase } \\
(\%)\end{array}$ \\
\hline Positif & 17 & 50,0 \\
\hline Negatif & 17 & 50,0 \\
\hline Total & 34 & 100.0 \\
\hline
\end{tabular}

Sumber : Hasil survei 2018

Merupakan ketentuan dalam pengambilan sampel penelitian yang terdiri atas sampel kasus beranggotakan pasien 
Hubungan Tingkat Pencahayaan, Kelembaban Udara, dan Ventilasi udara dengan Faktor...

Sukma Sahadewa, Eufemia, Edwin, Ni Luh, Shita

TBC dan sampel kontrol sebesar 17 orang $(50 \%)$.

9. Tingkat pencahayaan hunian kamar responden

Tabel 9. Distribusi Frekuensi Kasus dan Kontrol Berdasarkan Tingkat Pencahayaan Hunian Kamar Responden di Puskesmas Krian

\begin{tabular}{lcccccc}
\hline \multirow{2}{*}{$\begin{array}{l}\text { Tingkat } \\
\text { pencahayaan }\end{array}$} & \multicolumn{9}{c}{ TB } & \multirow{2}{*}{ Jumlah } \\
\cline { 2 - 6 } & \multicolumn{2}{c}{ Positif } & \multicolumn{2}{c}{ Negatif } & \\
\cline { 2 - 6 } & $\mathrm{n}$ & $\%$ & $\mathrm{n}$ & $\%$ & $\mathrm{n}$ & $\%$ \\
\hline Buruk & 8 & 47,1 & 2 & 11,8 & 10 & 29,4 \\
\hline Baik & 9 & 52,9 & 15 & 88,2 & 24 & 70,6 \\
\hline \multicolumn{1}{c}{ Total } & 17 & 100 & 17 & 100 & 34 & 100.0 \\
\hline
\end{tabular}

Sumber : Hasil survei 2018

Pada tabel di atas diketahui bahwa sebagian besar proporsi kelompok kasus yang menderita TB paru adalah yang tingkat pencahayaan hunian kamanya baik $(52,9 \%)$ lebih rendah dibandingkan dengan kelompok kontrol $(88,2 \%)$.

10. Kualitas Udara Lingkungan Responden

Tabel 10. Distribusi Frekuensi Kasus dan Kontrol Berdasarkan Kualitas Udara Lingkungan Responden di Puskesmas Krian

\begin{tabular}{lcccccc}
\hline \multirow{2}{*}{$\begin{array}{c}\text { Kualitas } \\
\text { Udara }\end{array}$} & \multicolumn{4}{c}{ TB } & \multirow{2}{*}{ Jumlah } \\
\cline { 2 - 6 } & \multicolumn{3}{c}{ Positif } & \multicolumn{2}{c}{ Negatif } & \\
\cline { 2 - 6 } & $\mathrm{n}$ & $\%$ & $\mathrm{n}$ & $\%$ & $\mathrm{n}$ & $\%$ \\
\hline Buruk & 7 & 41,2 & 1 & 5,9 & 8 & 23,5 \\
\hline Baik & 10 & 58,8 & 16 & 94,1 & 26 & 76,5 \\
\hline Total & 17 & 100 & 17 & 100 & 34 & 100.0 \\
\hline
\end{tabular}

Sumber : Hasil survei 2018

Pada Tabel 10. di atas diketahui bahwa sebagian besar proporsi kelompok kasus yang menderita TB paru adalah yang kualitas udara lingkungannya baik $(58,8 \%)$ lebih rendah dibandingkan dengan kelompok kontrol $(94,1 \%)$.
11. Ventilasi Hunian Kamar Responden

Tabel 11. Distribusi Frekuensi Kasus dan Kontrol Berdasarkan Ventilasi Hunian Kamar Responden di Puskesmas Krian

\begin{tabular}{lcccccc}
\hline \multirow{2}{*}{$\begin{array}{c}\text { Ventilasi } \\
\text { hunian } \\
\text { kamar }\end{array}$} & \multicolumn{4}{c}{ TB } & Jumlah \\
\cline { 2 - 5 } & Positif & \multicolumn{3}{c}{ Negatif } & & \\
\cline { 2 - 6 } & $\mathrm{n}$ & $\%$ & $\mathrm{~N}$ & $\%$ & $\mathrm{n}$ & $\%$ \\
\hline Buruk & 13 & 76,5 & 5 & 29,4 & 18 & 52,9 \\
\hline Baik & 4 & 23,5 & 12 & 70,6 & 16 & 47,1 \\
\hline Total & 17 & 100 & 17 & 100 & 34 & 100.0 \\
\hline Sumber $:$ Hasil survei & 2018 & & &
\end{tabular}

Sumber : Hasil survei 2018

Pada tabel di atas diketahui bahwa sebagian besar proporsi kelompok kasus yang menderita TB paru adalah yang ventilasi hunian kamarnya buruk (76,5\%) lebih tinggi dibandingkan dengan kelompok kontrol $(29,4 \%)$.

12. Kepadatan Hunian Kamar Responden

Tabel 12. Distribusi Frekuensi Kasus dan Kontrol Berdasarkan Kepadatan Hunian Kamar Responden di Puskesmas Krian

\begin{tabular}{lcccccc}
\hline \multirow{2}{*}{$\begin{array}{c}\text { Kepadatan } \\
\text { hunian kamar }\end{array}$} & \multicolumn{4}{c}{ TB } & Jumlah \\
\cline { 2 - 6 } & Positif & \multicolumn{2}{c}{ Negatif } & & \\
\cline { 2 - 6 } & $\mathrm{n}$ & $\%$ & $\mathrm{n}$ & $\%$ & $\mathrm{n}$ & $\%$ \\
\hline Buruk & 6 & 35,3 & 2 & 11,8 & 8 & 23,5 \\
\hline Baik & 11 & 64,7 & 15 & 88,2 & 26 & 76,5 \\
\hline Total & 17 & 100 & 17 & 100 & 34 & 100.0 \\
\hline Sumber: Hasil survei 2018 & & & &
\end{tabular}

Pada tabel di atas diketahui bahwa sebagian besar proporsi kelompok kasus yang menderita TB paru adalah yang kepadatan hunian kamarnya tidak padat $(64,7 \%)$ lebih rendah dibandingkan dengan kelompok kontrol (88,2\%).

\section{Analisa Data}

Setelah diketahui karakteristik masing-masing variabel (univariat) dapat diteruskan dengan analisis bivariat untuk 
ISSN 1978-2071 (Print); ISSN 2580-5967 (Online) Jurnal Ilmiah Kedokteran Wijaya Kusuma 8(2) : 118-130, September 2019

mengetahui hubungan antar variabel.

Berikut ini akan disajikan hasil pengujian

menggunakan uji odds ratio.

1. Pengaruh faktor risiko pencahayaan rumah terhadap kejadian tuberkulosis

Tabel 13. Kejadian Tuberkulosis Menurut Faktor Risiko Pencahayaan Rumah di Wilayah Puskesmas Krian

\begin{tabular}{|c|c|c|c|c|}
\hline \multirow{2}{*}{$\begin{array}{c}\text { Tingkat } \\
\text { pencaha } \\
\text { yaan }\end{array}$} & \multicolumn{2}{|c|}{ Tuberkulosis } & \multirow[b]{2}{*}{ Total } & \multirow{2}{*}{ Odds ratio } \\
\hline & Positif & Negatif & & \\
\hline Buruk & $\begin{array}{c}8 \\
(80,0 \%)\end{array}$ & $\begin{array}{c}2 \\
(20,0 \%)\end{array}$ & $\begin{array}{c}10 \\
(100 \%)\end{array}$ & \multirow{3}{*}{$\begin{array}{c}p \text {-value }= \\
0,024 \\
\text { OR }=6,667\end{array}$} \\
\hline Baik & $\begin{array}{c}9 \\
(37,5 \%)\end{array}$ & $\begin{array}{c}15 \\
(62,5 \%)\end{array}$ & $\begin{array}{c}24 \\
(100 \%)\end{array}$ & \\
\hline Total & $\begin{array}{c}17 \\
(50,0 \%)\end{array}$ & $\begin{array}{c}17 \\
(50,0 \%)\end{array}$ & $\begin{array}{c}34 \\
(100 \%)\end{array}$ & \\
\hline
\end{tabular}

Sumber : Hasil survei 2018

Hasil perhitungan odds ratio untuk pencahayaan dengan confidence interval $95 \%(\alpha=0,05)$. Didapatkan hubungan yang bermakna antara pencahayaan rumah tinggal dengan kejadian tuberkulosis dimana diperoleh $p$-value $=0,024(<0,05)$ dan nilai OR=6,667 (>1) berarti HO ditolak atau pencahayaan yang buruk mempunyai risiko 6,667 kali lebih besar untuk mengalami kejadian TB paru daripada responden yang menghuni rumah dengan tingkat pencahayaan yang baik.

2. Pengaruh faktor risiko kualitas udara rumah terhadap kejadian tuberkulosis

Tabel 14. Kejadian Tuberkulosis Menurut Faktor Risiko Kualitas Udara Rumah di Wilayah Puskesmas Krian

\begin{tabular}{ccccc}
\hline \multirow{2}{*}{$\begin{array}{c}\text { Kualitas } \\
\text { Udara }\end{array}$} & \multicolumn{2}{c}{ Tuberkulosis } & \multirow{2}{*}{ Total } & Odds ratio \\
\cline { 2 - 4 } Positif & Negatif & & \\
\hline Buruk & 7 & 1 & 8 & $p$-value= \\
& $(87,5 \%)$ & $(12,5 \%)$ & $(100 \%)$ & 0,015 \\
\hline
\end{tabular}

\begin{tabular}{|c|c|c|c|c|}
\hline Baik & $\begin{array}{c}10 \\
(38,5 \%)\end{array}$ & $\begin{array}{c}16 \\
(61,5 \%)\end{array}$ & $\begin{array}{c}26 \\
(100 \%)\end{array}$ & $O R=11,200$ \\
\hline Total & $\begin{array}{c}17 \\
(50,0 \%)\end{array}$ & $\begin{array}{c}17 \\
(50,0 \%)\end{array}$ & $\begin{array}{c}34 \\
(100 \%)\end{array}$ & \\
\hline
\end{tabular}

Hasil perhitungan odds ratio untuk kualitas udara dengan confidence interval 95\% $(\alpha=0,05)$. Didapatkan hubungan yang bermakna antara kualitas udara rumah tinggal dengan kejadian tuberkulosis dimana diperoleh $p$-value $=0,015 \quad(<0,05)$ dan nilai $\mathrm{OR}=11,200(>1)$ berarti HO ditolak atau kualitas udara yang buruk mempunyai risiko 11,200 kali lebih besar untuk mengalami kejadian TB paru daripada responden yang menghuni rumah dengan tingkat kualitas udara yang baik.

3. Pengaruh faktor risiko ventilasi terhadap kejadian tuberkulosis

Tabel 15. Kejadian Tuberkulosis Menurut Faktor Risiko Ventilasi Rumah di Wilayah Puskesmas Krian

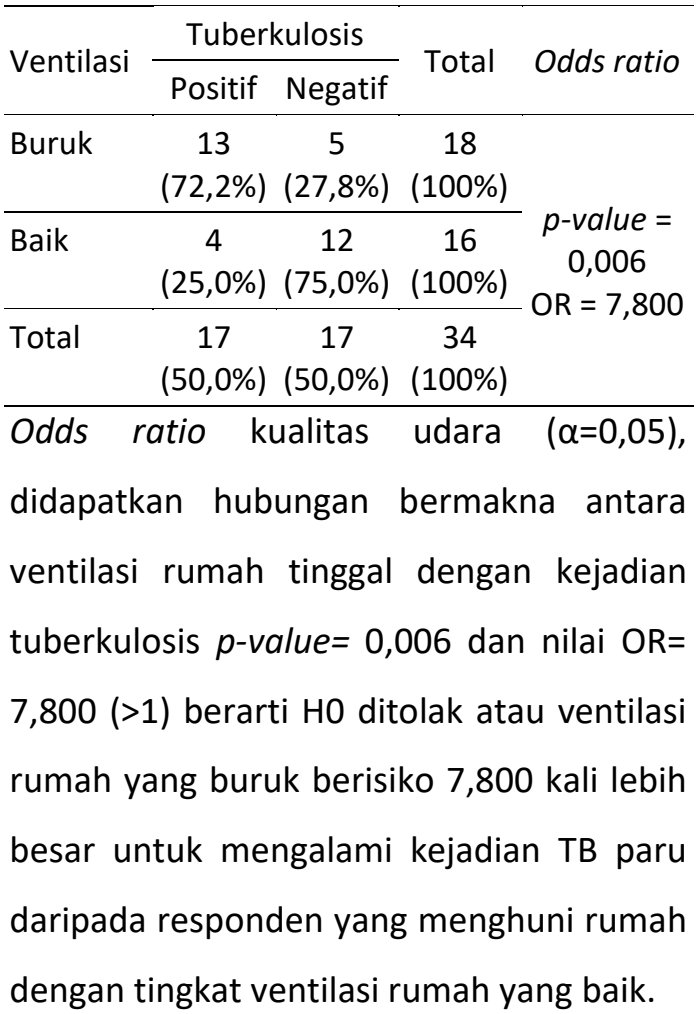


Hubungan Tingkat Pencahayaan, Kelembaban Udara, dan Ventilasi udara dengan Faktor...

Sukma Sahadewa, Eufemia, Edwin, Ni Luh, Shita

\section{PEMBAHASAN}

Hasil penelitian menunjukkan bahwa sebagian besar responden adalah laki-laki yaitu sebanyak 52,9\%, berpendidikan terakhir SMP yaitu sebanyak 70,6\%, mempunyai pekerjaan sebagai pegawai swasta/ wiraswasta yaitu sebanyak $58,8 \%$, menempati rumah yang mempunyai jenis dinding pasangan batako/ bata tanpa plester dengan kondisi dinding kering dan mempunyai bahan lantai rumah yang diplester/ keramik.

Hubungan antara tingkat pencahayaan dengan tuberkulosis

Dari hasil penelitian diketahui dari 17 rumah dengan Pencahayaan 80\% mengalami TB, sementara rumah dengan pencahayaan yang baik hanya $37,5 \%$ yang mengalami kejadian TB (Tabel 13) Hal ini menunjukkan bahwa masih banyak warga yang mempunyai bidang pencahayaan yang buruk dikarenakan tingkat pendidikan masih rendah $(70,6 \%$ berpendidikan SMP ke bawah) (Tabel 3). Untuk meningkatkan pengetahuan dan pemahaman tentang pentingnya luas bidang pencahaan perlu dilakukan penyuluhan mengenai pentingnya luas bidang pencahayaan dengan pencegahan penyakit TBDari hasil penelitian pada uji odds ratio pencahayaan yang buruk mempunyai risiko 6,667 kali lebih besar untuk mengalami kejadian TB paru daripada responden yang menghuni rumah dengan tingkat pencahayaan yang baik. Hal ini sejalan dengan hasil penelitian yang dilakukan oleh Musadad (2001), hasil penelitiannya menunjukkan ada hubungan yang signifikan antara pencahayaan matahari langsung dengan kejadian tuberkulosis paru.

Adanya hubungan yang signifikan antara pencahayaan alami dengan

kejadian TB paru berkaitan dengan sifat bakteri TB yang tidak tahan terhadap sinar matahari (Widoyono, 2011). Cahaya matahari mempunyai daya untuk membunuh bakteri minimal masuk 60 lux dengan syarat tidak menyilaukan (Ruswanto, 2010).

Kondisi pencahayaan merupakan faktor risiko yang cukup signifikan hal ini dapat dilihat dari penelitian di atas, dengan pencahayaan yang kurang maka kuman TB Paru yang ada di lingkungan tidak mati karena cahaya matahari merupakan salah satu faktor yang dapat membunuh kuman TB Paru, sehingga jika pencahayaan baik maka penularan dan perkembangbiakan kuman bisa dicegah.

\footnotetext{
Hubungan antara kualitas udara dengan tuberkulosis

Tabel 10 menggambarkan kualitas udara di lingkungan responden 76,5\% diantarannya memenuhi syarat (baik). Dikarenakan rumah dengan kualitas udara yang buruk kemungkinan mengandung
} 
ISSN 1978-2071 (Print); ISSN 2580-5967 (Online) Jurnal IImiah Kedokteran Wijaya Kusuma 8(2) : 118-130, September 2019

bakteri Mycobacterium tuberculosis sehingga memiliki risiko untuk terjadinya TB paru 3 kali lebih besar dibandingkan dengan rumah yang udaranya tidak mengandung bakteri Mycobacterium tuberculosis dikarenakan infeksi tuberkulosis diawali seseorang menghirup basil Mycobacteroium tuberculosis (Somantri, 2007)

Bakteri ini sangat berperan dalam penularan dan penyebab terjadinya penyakit tuberkulosis (TB) paru jika bakteri yang melayang di udara tersebut terhirup oleh manusia sehat. Menurut Jawetz dan Adelberg's (2008), bakteri yang terhirup akan masuk ke alveoli melalui jalan nafas, alveoli adalah tempat bakteri berkumpul dan bakteri mulai memperbanyak diri. Mycobacterium tuberculosis juga dapat masuk ke bagian tubuh lainnya melalui system limfe dan cairan tubuh. Sistem imun tubuh akan merespon dengan cara melakukan reaksi inflamasi. Fagosit menelan bakteri, dan limfosit spesifik tuberkulosis menghancurkan bakteri dan jaringan normal. Reaksi jaringan tersebut menimbulkan penumpukan eksudat di dalam alveoli yang bisa mengakibatkan bronchopneumonia. Setelah pemajanan biasanya terjadi infeksi awal dua sampai sepuluh minggu.

Bakteri TB paru dapat berada disemua tempat, hal ini sesuai dengan teori yang disebutkan oleh (Muttaqin, 2012), saat bersin, batuk, atau berbicara, seseorang klien TB paru secara tidak sengaja menyebarkan doplet nuklei dan terjatuh ke lantai, tanah, atau tempat lainnya. Paparan sinar matahari langsung atau panasnya suhu udara, menyebabkan doplet nuklei tersebut dapat menguap. Menguapnya droplet bakteri ke udara dibantu dengan pergerakan aliran angin yang menyebabkan bakteri tuberkulosis yang terkandung di dalam doplet nuklei terbang melayang mengikuti aliran udara.

Kualitas udara dipengaruhi oleh suhu dan kelembaban dalam ruangan serta volume sinar matahari yang dapat masuk kedalam ruangan tersebut. Kelembaban merupakan faktor risiko untuk terjadinya tuberkulosis (TB) paru karena kurangnya sinar matahari yang masuk ke dalam rumah akan menciptakan suasana gelap dan lembab sehingga kuman termasuk bakteri TB paru dapat tahan berhari-hari sampai berbulan-bulan di dalam rumah (Fahreza, 2012).

Hasil penelitian dengan uji odds ratio menunjukkan kualitas udara yang buruk mempunyai risiko 11,200 kali lebih besar untuk mengalami kejadian TB paru daripada responden yang menghuni rumah dengan tingkat kualitas udara yang baik. Kualitas udara dipengaruhi oleh tingkat 
Hubungan Tingkat Pencahayaan, Kelembaban Udara, dan Ventilasi udara dengan Faktor...

Sukma Sahadewa, Eufemia, Edwin, Ni Luh, Shita

kelembaban dan suhu dalam ruangan tersebut.

Menurut Bawole dkk (2014) kelembaban berperan bagi pertumbuhan mikroorganisme termasuk bakteri tuberkulosis (TB) paru. Kelembaban rumah yang tinggi dapat meningkatkan kehidupan bakteri tuberkulosis. Dan ada rentang suhu yang disukai oleh bakteri Mycobacterium tuberculosis, yaitu pada rentang suhu tersebut terdapat suhu optimum tertentu yang memungkinkan bakteri tersebut tumbuh dengan cepat. Mycobacterium tuberculosis merupakan bakteri mesofi lik yang tumbuh cepat dalam rentang antara antara $25^{\circ} \mathrm{C}-40^{\circ} \mathrm{C}$, tetapi bakteri akan tumbuh secara optimal pada suhu $31^{\circ} \mathrm{C}-$ $37^{\circ} \mathrm{C}$. (Gould dan Brooker, 2003)

\section{Hubungan antara ventilasi dengan tuberkulosis}

Berdasarkan hasil penelitian dengan uji odds ratio $=7,800(>1)$ berarti HO ditolak atau ventilasi rumah yang buruk mempunyai risiko 7,800 kali lebih besar untuk mengalami kejadian TB paru daripada responden yang menghuni rumah dengan tingkat ventilasi rumah yang baik. Hal ini terjadi dimana kondisi ventilasi yang tidak memenuhi syarat kurang atau tidak ada pertukaran udara yang baik dalam ruangan sehingga menyebabkan bakteri-bakteri penyakit terkhusus bakteri tuberculosis tidak dapat segera mati (Hariza,2011)

Hasil penelitian ini juga sejalan dengan penelitian Putra (2011) yang menunjukkan ada hubungan yang signifikan antara kondisi ventilasi dengan kejadian TB paru dengan nilai OR 5,741.

Tabel 11 diketahui bahwa luas bidang ventilasi $10 \%$ atau kurang luas lantai buruk sebanyak 52,9\%. Dari 100\% rumah dengan ventilasi buruk $72,2 \%$ diantarannya ada anggota keluarga yang mengalami TB, sementara dari 100\% rumah dengan ventilasi yang baik hanya 25\% yang mengalami kejadian TB (Tabel 15). Masih banyaknya warga yang mempunyai ventilasi yang buruk bisa dikarenakan tingkat pendidikan yang masih rendah $(70,6 \%$ berpendidikan SMP ke bawah) (Tabel 3). Untuk meningkatkan pengetahuan dan pemahaman tentang pentingnya ventilasi rumah perlu dilakukan penyuluhan. Penyuluhan mengenai pentingnya ventilasi rumah untuk pencegahan penyakit TBC, diantaranya menyangkut berapa luas ventilasi yang dibutuhkan untuk setiap ruangan yang ada di rumah dan pentingnya ventilasi dalam membunuh bakteri TBC.

Ventilasi merupakan kondisi rumah yang memiliki sirkulasi udara keluar masuk yang cukup dengan luas ventilasi minimal $10 \%$ dari luas lantai (Lumban, 
ISSN 1978-2071 (Print); ISSN 2580-5967 (Online) Jurnal IImiah Kedokteran Wijaya Kusuma 8(2) : 118-130, September 2019

2008). Ruangan dengan luas ventilasi yang tidak memenuhi syarat $(<10 \%$ luas lantai) menyebabkan tingginya kelembaban dan suhu dalam ruangan karena kurangnya pertukaran udara dari luar rumah sehingga memberi kesempatan kepada bakteri TB untuk dapat bertahan hidup di dalam ruang tersebut karena sifat bakteri TB yang mampu bertahan hidup di dalam ruangan yang gelap dan lembab (Ayomi, 2012).

Dari hasil penelitian diatas dapat disimpulkan bahwa ventilasi yang buruk mempunyai pengaruh besar terhadap kejadian TB paru, karena ada atau tidaknya ventilasi mempengaruhi faktor lain yang menjadi pemicu kuman tuberkulosis tumbuh dan berkembang biak dengan baik

\section{KESIMPULAN}

1. Terdapat hubungan yang bermakna antara pencahayaan rumah tinggal sebagai faktor risiko kejadian tuberkulosis paru di Puskesmas Krian, pencahayaan yang buruk mempunyai risiko 6,667 kali lebih besar untuk mengalami kejadian TB paru daripada responden yang menghuni rumah dengan tingkat pencahayaan yang baik

2. Terdapat hubungan yang bermakna antara kualitas udara rumah tinggal sebagai faktor risiko terjadinya tuberkulosis paru di Puskesmas Krian. Kualitas udara yang buruk mempunyai risiko 11,200 kali lebih besar untuk mengalami kejadian TB paru daripada responden yang menghuni rumah dengan tingkat kualitas udara yang baik

3. Terdapat hubungan yang bermakna antara ventilasi rumah tinggal sebagai faktor risiko kejadian tuberkulosis paru di Puskesmas Krian. Ventilasi rumah yang buruk mempunyai risiko 7,800 kali lebih besar untuk mengalami kejadian TB paru daripada responden yang menghuni rumah dengan tingkat ventilasi rumah yang baik

\section{SARAN}

1. Untuk meningkatkan pengetahuan dan pemahaman masyarakat tentang pencegahan penyakit TB, maka perlu dilakukan penyuluhan mengenai berapa luas bidang pencahayaan yang dibutuhkan oleh setiap rumah dalam mencegah penyakit TB. Selain itu diharapkan untuk masyarakat agar mengupayakan rumah dengan luas bidang pencahayaan yang < $10 \%$ luas lantai diperlebar sesuai persyaratan.

2. Untuk meningkatkan pengetahuan dan pemahaman tentang pentingnya ventilasi rumah yang baik melalui penyuluhan mengenai berapa luas ventilasi yang dibutuhkan untuk setiap 
Hubungan Tingkat Pencahayaan, Kelembaban Udara, dan Ventilasi udara dengan Faktor...

Sukma Sahadewa, Eufemia, Edwin, Ni Luh, Shita

ruangan yang ada di rumah dan pentingnya ventilasi dalam membunuh bakteri TBC. Mengupayakan ventilasi yang masih < 10\% luas lantai diperlebar untuk memperlancar pertukaran udara dengan baik. Untuk meningkatkan pengetahuan dan pemahaman masyarakat tentang pencegahan penyakit TBC, maka perlu dilakukan penyuluhan mengenai risiko kualitas udara terhadap kejadian penyakit TBC terutama yang menyangkut ruangan ruangan yang lembab dan sempit serta tidak terpapar sinar matahari.

\section{DAFTAR PUSTAKA}

Adnani H, 2011, Ilmu Kesehatan Masyarakat. Yogyakarta : Nuha Medika

Agustian dan Mahesa. 2014. Diskusi terbuka online UKMPPD batch 1. Diakses 24 November 2015

Ayomi AC. 2012. Faktor Risiko Lingkungan Fisik Rumah dan Karakteristik Wilayah Sebagai Determinan Kejadian Penyakit Tuberkulosis Paru di Wilayah Kerja Puskesmas Sentani Kabupaten Jayapura Provinsi Papua.Jurnal Kesehatan Lingkungan Indonesia. Vol.11. No. 1/ April 2012
Badan Litbangkes Kemenkes RI, 2011. Laporan Akhir Riset Fasilitas Kesehatan tahun 2011, Jakarta

Bawole, S.T.T., Rattu A.J.M., Posangi, Jimmy. 2014. Faktor Risiko Lingkungan Fisik Rumah terhadap Kejadian TB Paru di Kecamatan Likupang Barat Kabupaten Minahasa. Jurnal Kesehatan halaman

Depkes RI, 2017, Peraturan Menteri Kesehatan Republik Indonesia No. 9 Tahun 2017 tentang Apotek, Jakarta

Fahreza, E.U. 2012. Hubungan Antara Kualitas Fisik Rumah dan Kejadian Tuberkolosis Paru dengan Basil Tahan Asam Positif di Balai Kesehatan Paru Masyarakat Semarang. Jurnal Kedokteran Muhammadiyah halaman

Gould, D., Brooker, C. 2013. Mikrobiologi Terapaan Untuk Perawat. Jakarta. EGC

Jawetz, M., Adelberg's. 2008. Mikrobiologi Kedokteran. Jakarta. Salemba Medika

Kemenkes. Rencana Strategis Kementerian Kesehatan Tahun 2015-2019. Jakarta: Kementerian Kesehatan RI; 2015

Lumban T. Tobing. 2008. Pengaruh Penderita TB Paru dan Kondisi 
ISSN 1978-2071 (Print); ISSN 2580-5967 (Online) Jurnal IImiah Kedokteran Wijaya Kusuma 8(2) : 118-130, September 2019

Rumah terhadap Pencegahan

Potensi Penularan TB Paru

pada Keluarga di Kabupaten

Tapanuli Utara Tahun 2008,

Medan, Program Pascasarjana

Universitas Sumatera Utara, Tesis

Musadad,. 2001. Jurnal Hubungan Faktor

Lingkungan Rumah dengan

Kejadian Penularan TB Paru di

Rumah Tangga Tahun 2001

Muttaqin, A. 2012. Buku Ajar Asuhan

Keperawatan Klien dengan

Gangguan Sistem Pernafasan

Naga S. Sholeh 2014, Paduan Lengkap IImu

Penyakit Dalam, Penerbit Diva

Press, Yogyakarta

Putra, N.R. 2011. Hubungan Prilaku dan Kondisi Sanitasi Rumah Dengan Kejadian TB Paru di Kota Solok Tahun 2011. Program Studi IImu Kesehatan Masyarakat Fakultas
Kedokteran Universitas Andalas. Padang

Ruswanto, B. 2010. Analisis Spasial Sebaran Kasus Tuberkulosis Paru Ditinjau dari Faktor Lingkungan Dalam dan Luar Rumah di Kabupaten Pekalongan. Tesis. Program Pasca Sarjana Universitas Diponegoro Semarang

Somantri, I. 2007. Keperawatan Medikal Bedah: Asuhan Keperawatan pada Pasien demean Gangguan Sistem Pernapasan

Widoyono, 2011, Penyakit Tropis Epidemiologi, Penularan, Pencegahan dan Pemberantasannya Edisi Kedua, Erlangga, Jakarta 